\title{
RELATIONSHIP BETWEEN TREE ECOLOGICAL PARAMETERS AND SOIL ORGANISMS ABUNDANCE IN ECOLOGICAL ZONES OF BAYELSA STATE, NIGERIA
}

\author{
Lawrence, E.U., Oyegun C.U. and Eludoyin O.S. \\ Department of Geography and Environmental Management, University of Port Harcourt, Nigeria
}

https://doi.org/10.35410/IJAEB.2021.5634

\begin{abstract}
The study examined the relationship between tree ecological parameters and abundance of soil organisms in ecological zones of Bayelsa State, Nigeria. The study adopted quasi experimental research design. A quadrat of $100 \mathrm{~m} \times 100 \mathrm{~m}$ was delimited in the relatively less disturbed forest in each ecological zone from which twenty (20) sub-quadrats were randomly selected for data collection on plants and soil organisms (earthworm, arthropods, fungi and bacteria) abundance at different soil depths $(0-15 \mathrm{~cm}, 15-30 \mathrm{~cm}, 30-45 \mathrm{~cm})$. Both descriptive and inferential statistics were used for data analysis. Findings showed that a total of 251 earthworm population was found in the entire area with the highest $(52.1 \%)$ at the topsoil in the freshwater swamp (FWS) while 176 individual species of earthworm recorded in the mangrove (MG) with highest in the topsoil (63.64\%). Soil arthropods abundance was significantly higher between FWS and MG at $\mathrm{p}<0.05$. Earthworm abundance was significantly correlated with tree composition ( $\mathrm{r}=-0.459)$, tree density $(\mathrm{r}=0.543)$ and tree density $(\mathrm{r}=0.581)$ in the FWS while soil fungi was significantly correlated with tree richness $(\mathrm{r}=0.445)$ at the topsoil in the FWS. In addition, at $15-30 \mathrm{~cm}$ soil depth in the FWS, only soil fungi was correlated with tree composition $(r=0.668)$ and tree richness $(r=0.550)$. At the soil depth of $30-45$, only soil bacteria was significantly correlated with tree richness $(\mathrm{r}=0.624)$ and tree density $(\mathrm{r}=0.464)$. In $\mathrm{MG}$, at the soil depth of $0-15 \mathrm{~cm}$, soil arthropods abundance was significantly correlated with tree composition $(r=0.464)$. At $15-30 \mathrm{~cm}$, soil bacteria was significantly correlated with tree richness $(\mathrm{r}=0.582)$ and tree density $(\mathrm{r}=0.632)$ while soil fungi was significantly correlated with number of trees $(\mathrm{r}=0.611)$, tree diversity $(\mathrm{r}=0.624)$, tree richness $(r=0.520)$ and tree density $(r=0.632)$. At the soil depth of $30-45 \mathrm{~cm}$, soil fungi correlated significantly with number of trees $(r=0.474)$. The study recommended that plant conservation is important to protect the survival of soil organisms.
\end{abstract}

Keywords: Soil organisms, Ecological parameters, Ecological zones, Correlation, Bayelsa State.

\section{INTRODUCTION}

Tropical forests have some resemblance at the global scale with respect to high productivity, rapid nutrient turnover, highly weathered soil, and low soil $\mathrm{pH}$, but they also have extensive difference in soils and corresponding plant communities (Fujii et al, 2018). This is because different tropical regions have distinct geological histories and plant communities (Corlett \& Primack, 2006). Differences in climate, geology, and topography always result to diverse patterns and processes of plants, soils and their interaction

ns (Vitousek, 2004). Studies have reported associations between soil properties, such as $\mathrm{pH}$ or $\mathrm{P}$ with forest properties (i.e. forest aboveground biomass or species distributions (Condit et al., 
Vol. 06, No. 03; 2021

ISSN: $2456-8643$

2013). Other studies have failed to link soil properties and plant species distribution due to the narrow variation of soil chemical properties and low resolution of soil classification (Sollins, 1998). Comparison between tropical regions can provide variation in plant species, soil types, and availability of nutrients with which to investigate the importance of soils or plants on biodiversity and functions in tropical forests (Fujii et al., 2018).

Soil is not a state factor for plant growth, as soil formation is influenced by plants (biota) climate, geology, topography and time (Fujii et al., 2018). Soil can influence plant physiological processes, while plants can also change soil processes, a concept known as plant-soil feedback. The cause-effect in plant-soil processes or plant-soil feedback are linked to soil chronosequences, plant impacts on soil processes, strategies of nutrient acquisition and utilization (allocation), and niche differentiation related to soil nutrients. Soil is known for its tremendous spatial (vertical and horizontal) and temporal heterogeneity which gives rise to a wide range of surface types, aggregate and pore sizes and microclimates, and a range of resources and resource partitioning in space and time. This complexity is an obstacle to the use of single measures (e.g. $\mathrm{pH}$, organic matter content) as broadly- applicable indicators of soil health and ecosystem function (Baveye et al. 2016), instead simple indicators need to be emergent or at least well linked to underlying mechanisms. The physical environment can be considered as a template on which organisms and ecological systems operate; for many soil organisms, especially micro-organisms, the architecture of the soil pore network defines the effective habitat space in soil (Young \& Ritz, 2000). The amount and nature of the pore space in soil are dependent not only on soil texture but also on the aggregation of mineral particles and soil organic matter (SOM), which is, the formation and stabilization of soil structure. Most soil organisms have limited migration capacity (Fitter et al. 2005) and motility of many soil species is low compared to the scale of resource patchiness (Ettema \& Wardle, 2002). Soil organisms also often enter inactive or dormant states in unfavourable conditions, so that diversity is preserved even under extreme conditions; this is analogous to the role of soil seed- banks in preserving plant diversity (Ettema \& Wardle, 2002). Hence, organisms' response to the physical environment may exhibit patterns that vary between species and are constrained by the geometry of the environment (Williams et al., 2002).

Soil micro-organisms are key drivers of biogeochemical cycles in plant-soil systems. In addition to differences in vegetation, the geographical distribution of the soil fauna also vary markedly among tropical regions. Termites are predominately soil-feeders in Africa (Davies et al., 2003). Fungus-growing termites (Macrotermitinae with Termitomyces) rely on fungal cellulases for litter decomposition in Asia and Africa (Aanen et al., 2009), while leaf-cutting ants develop similar strategy (dependence on fungal cellulases) to decompose alive leaf in Neotropics (North et al., 1997). The stag beetles (Lucanidae), which form the earliest radiation of Scarabaeoidea, feed on dead woods and are commonly found in humid tropical forests, while the other groups of Scarabaeoidea that feed dung or humus are specialized to angiosperm species and their habitats (Ahrens et al., 2014). In contrast to localization of soil fauna, most of micro-organisms are considered to be cosmopolitan, because spores can be easily dispersed. There is a metaphor that "in microorganisms, everything is everywhere, the environment selects", although this paradigm has not been supported by evidence (Foissner, 2006). The environmental selection can cause differences in composition of soil microbial communities, but effects of their functions are not simple due to functional redundancy (Rousk et al., 2010). The microbial activity of soil 
Vol. 06, No. 03; 2021

ISSN: $2456-8643$

organic matter decomposition is generally high under humid tropical climate (Hayakawa et al., 2013), leading to similarities among different tropical regions. On the other hand, variability in substrate (litter) quality and soil habitat causes wide variation in soil microbial communities and functions of nutrient cycles in forest soils. Trees accumulate secondary metabolic compounds such as lignin and tannin for defense against herbivores, physical strength, and disease resistance (Weng and Chapple, 2010). Various studies have been given to understand interrelationship between the tree species, soil microbial and physico-chemical properties of forest soil. Further, studies undertaken on varied forest soils confirm that various biotic and abiotic factors influence the microbial biomass, composition and activity (Landesman and Dighton 2011; Chandra et al., 2016); especially in the forest ecosystem. Still, the information is limited in the relatively disturbed forests in the swamp forest and mangrove ecosystems. There are still few studies showing the impacts of vegetation dynamics on soil moisture, soil temperature and soil microbes knowing fully that these soil properties are very essential in the soil ecosystem services (Adhikari \& Hartemink, 2015). The present study examined the interactions between ecological parameters of tree and the abundance of soil organisms across ecological zones in Bayelsa State, Nigeria.

\section{MATERIALS AND METHODS}

The study was carried out in Bayelsa State, Nigeria. Bayelsa State is geographically located with latitude $4^{0} 15^{\prime}$ North and latitude $5^{0} 23^{\prime}$ South and longitude $05^{\circ} 22^{\prime}$ west and $06^{\circ} 45^{\prime}$ East. It shares boundaries with Delta State on the North, Rivers State on the East and the Atlantic Ocean on the West and South. The State has a land mass of 21, $110 \mathrm{Sq} \mathrm{km} / 10,773$ square miles. Bayelsa is a State in Southern Nigeria in the core Niger Delta region. The area lies almost entirely below sea level with a maze of meandering creeks and rivers in the south, all flow into the Atlantic ocean via the major rivers such as San Bartholomew, Brass, Nun, Ramos, Santa Barbara, St Nicholas, Sangana, Fishtown, Ikebiri creek, Middleton, Digatoro creek, Penington and Dobo (Figure 1). The study area has the same weather condition like Port Harcourt as a region. The climatic condition is the tropical climate (Ologunorisa \& Adejuwon, 2003). The months of February and March records the highest temperature of $33^{\circ} \mathrm{C}$, while the months of January and December records the lowest temperature of $21^{\circ} \mathrm{C}$. Temperature rises through the months of October, November and December. The monthly rainfall in the area is slightly predictable due to climate change in the world today, temporally rainfall decreases from the months of October to February which is the dry season (Ologunorisa and Adejuwon, 2003). The rainfall in the area is greatly influenced by the Inter Tropical Discontinuity (ITD), due to its location. Rainfall peaks in July and September with a little dry season in August (August break).The area experiences about $2476 \mathrm{~mm}$ of precipitation falls annually. There are three major soil groups identified in the Niger Delta, namely: the marine and fluvial marine sediments; the mangrove swamp alluvial soils; and freshwater brown loams and sandy loams. The "upland" area was originally occupied by rainforest which has been drastically modified by human activities. In most places, economic trees, particularly oil palm, have been preserved and thus the sobriquet for this vegetation as "oil palm bush." The riverine area is divided into three main hydro vegetation zones namely, the beach ridge zone, the saltwater zone and the freshwater zone. In terms of general surface features, the area is very unique, and falls within the coastal belt dominated by low lying coastal plain which belongs to the structural sedimentary formation of the recent Niger Delta. Umeuduji 
Vol. 06, No. 03; 2021

ISSN: $2456-8643$

and Aisebeogun (1999) identified that the area is within the belt of fresh water raffia dominated wetlands with heights which vary between $10-25 \mathrm{~m}$ above sea level.

The study adopted quasi experimental research design. A quadrat of $100 \mathrm{~m} \times 100 \mathrm{~m}$ was delimited in the relatively less disturbed forest or not disturbed forest in each ecological zone of Bayelsa State (Shen, 2011). This quadrat was sub-divided into quadrats of $20 \mathrm{~m} \times 20 \mathrm{~m}$ from which twenty (20) quadrats were randomly selected for data collection on plants and soil organisms in each ecological belt. The sample plots were delimited with pegs and tagged with red coloured ribbon for easy identification of the boundaries. The sampling methods adopted for this study were stratified and simple random sampling techniques. The tree plants species were identified with the assistance of a Taxonomist from the Department of Forestry and Wildlife Management, University of Port Harcourt within the sixteen sub-quadrats selected for the study. Thereafter, overstorey data were collected on the total tree composition and number of individual trees. The tree composition and number of individual trees were used to determine the plant richness and diversity in each ecological zone. Species composition of vascular plants in the study area was determined by identifying the plant species while the population of individual species was determined by direct counting of the population of each plant species in the $20 \mathrm{~m} \times 20 \mathrm{~m}$ quadrats. The species composition data of the vascular plants was used to compute species density, diversity, richness, and evenness of the vascular plants in the study area. The species diversity index (H') was computed using Simpson's index (Simpson, 1949). The value of $\mathrm{H}$ ranges from 0 to 1 . With this index, 0 represents maximum diversity and, 1 , no diversity. That is, the bigger the value the lower the diversity. To remove the inverse relationship between Simpson's index and actual diversity of a community, the diversity index is subtracted from 1 . The value also ranges from 0 to 1 but the interpretation is the higher the value, the higher the diversity and vice versa (Chima and Omokhua, 2011). Species density is simply the number of individual species per unit area and is generally reported as the number of individuals per hectare. The species richness (the number of species in a given community) was determined using Margalef's index (Margalef, 1958). Descriptive statistics was used to describe the mean values of the plant parameters and abundance of soil organisms while inferential statistics involving Spearman's correlation statistics were used to determine the associations between the tree ecological parameters and the abundance of soil organisms. Data were presented in tables and graphs.

\section{RESULTS AND DISCUSSIONS} Abundance of Soil Organisms

The abundance of earthworm in each ecological zone across the soil profile is presented in Table 1 worm in each ecological zone. A total of 251 earthworm individual population were enumerated in 20 sample plots within soil profile $0-15 \mathrm{~cm}(131), 15-30 \mathrm{~cm}(68)$ and $30-45 \mathrm{~cm}(52)$ under the freshwater swamp ecological zone and a total of 176 earthworm individual population which were also enumerated in 20 sample plots within soil profile $0-15 \mathrm{~cm}(112), 15-30 \mathrm{~cm}(40)$ and $30-45 \mathrm{~cm}$ (24) in the mangrove ecological zone. Thus, a total of 427 earthworm populations were enumerated in all sampled 20 plots across the soil profile in each ecological zone. Comparing the earthworm population in each ecological zone as indicated by topsoil and sub soil, it was revealed that Eisenia andrei was highest (62) individuals of a species in the freshwater swamp and (35) individuals of the specie in the mangrove soil with a total of 97 individuals of a species which accounts for $22.7 \%$ from the overall total population of species of 
$427(100.0 \%)$ individual species. This was followed by Eisenia fetida which recorded (61) individuals of a specie in the freshwater zone and (33) individuals of a specie in the mangrove zone with an overall total of 94 (22.0\%) individuals of a species. The third highest enumerated earthworm individual species was Lumbricus terrestris which recorded (26) individuals of a specie in the freshwater swamp zone and (24) individuals of a specie in the mangrove ecological zone and accounted for an overall total of $50(11.7 \%)$ individuals of a specie in the study area. Generally, the total population of earthworm species was highest in the freshwater swamp ecological zone with respect to soil depth (topsoil and sub soils) than in the mangrove ecological zone. It was observed that the population of earthworm was highest in the topsoil in both freshwater swamp and mangrove.

Table 1: Total Frequency of Earthworm Frequency per soil profile across ecological zones

\begin{tabular}{|c|c|c|c|c|c|c|c|c|c|c|}
\hline \multirow{2}{*}{$\begin{array}{l}\text { Earthworm } \\
\text { Species }\end{array}$} & \multicolumn{3}{|c|}{ Freshwater swamp } & \multirow[t]{2}{*}{ Total } & \multicolumn{3}{|c|}{ Mangrove } & \multirow[t]{2}{*}{ Total } & \multirow{2}{*}{$\begin{array}{l}\text { Overal } \\
1 \text { Total }\end{array}$} & \multirow{2}{*}{$\begin{array}{l}\text { Overall } \\
\text { Total } \\
\text { Percentag } \\
\text { e }(\%)\end{array}$} \\
\hline & $0-15$ & $\begin{array}{l}15- \\
30\end{array}$ & $\begin{array}{l}30- \\
45\end{array}$ & & $0-15$ & $\begin{array}{l}15- \\
30\end{array}$ & $\begin{array}{l}30- \\
45\end{array}$ & & & \\
\hline $\begin{array}{l}\text { Eisenia } \\
\text { andrei }\end{array}$ & 36 & 12 & 14 & 62 & 24 & 6 & 5 & 35 & 97 & 22.7 \\
\hline $\begin{array}{l}\text { Eisenia } \\
\text { fetida }\end{array}$ & 29 & 20 & 12 & 61 & 29 & 3 & 1 & 33 & 94 & 22.0 \\
\hline $\begin{array}{l}\text { Eisenia } \\
\text { hortensis }\end{array}$ & 10 & 4 & 4 & 18 & 5 & 7 & 3 & 15 & 33 & 7.7 \\
\hline $\begin{array}{l}\text { Eudrilius } \\
\text { eugeniae }\end{array}$ & 9 & 4 & 1 & 14 & 24 & 6 & 1 & 31 & 45 & 10.5 \\
\hline $\begin{array}{l}\text { Eutoreutus } \\
\text { abinsanus }\end{array}$ & 13 & 5 & 3 & 21 & 2 & 0 & 0 & 2 & 23 & 5.4 \\
\hline $\begin{array}{l}\text { Hyperiodrilu } \\
\text { s africanus }\end{array}$ & 13 & 5 & 4 & 22 & 10 & 3 & 2 & 15 & 37 & 8.7 \\
\hline $\begin{array}{l}\text { Hyperiodrilu } \\
\text { s } \\
\text { oshogbensis }\end{array}$ & 1 & 2 & 3 & 6 & 1 & 0 & 0 & 1 & 7 & 1.6 \\
\hline $\begin{array}{l}\text { Iridodrilus } \\
\text { tonyii }\end{array}$ & 0 & 0 & 0 & $\mathbf{0}$ & 5 & 1 & 1 & 7 & 7 & 1.6 \\
\hline $\begin{array}{l}\text { Lumbricus } \\
\text { rubelius }\end{array}$ & 13 & 7 & 1 & 21 & 0 & 6 & 7 & 13 & 34 & 8.0 \\
\hline
\end{tabular}


Vol. 06, No. 03; 2021

ISSN: $2456-8643$

\begin{tabular}{|l|l|l|l|l|l|l|l|l|l|l|}
\hline $\begin{array}{l}\text { Lumbricus } \\
\text { terrestris }\end{array}$ & 7 & 9 & 10 & $\mathbf{2 6}$ & 12 & 8 & 4 & $\mathbf{2 4}$ & $\mathbf{5 0}$ & 11.7 \\
\hline Total & $\mathbf{1 3 1}$ & $\mathbf{6 8}$ & $\mathbf{5 2}$ & $\mathbf{2 5 1}$ & $\mathbf{1 1 2}$ & $\mathbf{4 0}$ & $\mathbf{2 4}$ & $\mathbf{1 7 6}$ & $\mathbf{4 2 7}$ & $\mathbf{1 0 0 . 0}$ \\
\hline $\begin{array}{l}\text { Percentage } \\
(\boldsymbol{\%})\end{array}$ & $\mathbf{5 2 . 1}$ & $\mathbf{2 7 . 0}$ & $\mathbf{2 0 . 7}$ & $\mathbf{1 0 0 . 0}$ & $\mathbf{6 3 . 6}$ & $\mathbf{2 2 . 7}$ & $\mathbf{1 3 . 6}$ & $\mathbf{1 0 0 . 0}$ & & \\
\hline
\end{tabular}

The information on Table 2 is for the frequency and percentages of soil bacteria species in each soil profile and in each ecological zone. The distribution under the FWS zone with respect to varying soil depths showed that Bacillus recorded a total of 42 species count; Pseudomonas recorded 35 species count; Micrococcus recorded 2 species count only at soil depth of $0-15 \mathrm{~cm}$; Aeromonas recorded 40 species count; Enterobaeter recorded 33 species count; Salmonella recorded 6 species count; Staphylococcus recorded 27 species count; Protens recorded no species count; while Flavobacterium recorded 4 species count only at soil depth of $30-45 \mathrm{~cm}$. The total species count for the 8 identified soil bacteria individual species was 66 for soil depth of $0-15 \mathrm{~cm}$; 63 counts for soil depth of $15-30 \mathrm{~cm}$ and 60 counts for soil depth of $30-45 \mathrm{~cm}$. This makes an overall total of 189 soil bacteria individual species under the FWS zone with respect to soil depths. In the mangrove ecological zone with respect to varying soil depths, the analysis showed that Bacillus recorded a total of 48 species count; Pseudomonas recorded 42 species count; Micrococcus recorded 20 species count; Aeromonas recorded 39 species count; Enterobaeter recorded 28 species count; Salmonella recorded 33 species count; Staphylococcus recorded 12 species count only in soil depth of $0-15 \mathrm{~cm}$ and $15-30 \mathrm{~cm}$; Protens recorded 6 species count only in soil depth of $0-15 \mathrm{~cm}$ and $15-30 \mathrm{~cm}$; while Flavobacterium recorded 0 species count only. The total species count for the 8 identified soil bacteria individual species was 79 for soil depth of 0 $15 \mathrm{~cm} ; 82$ counts for soil depth of $15-30 \mathrm{~cm}$ and 67 counts for soil depth of $30-45 \mathrm{~cm}$. This makes an overall total of 228 soil bacteria individual species under the mangrove ecological zone with respect to soil depths. Comparatively, the overall total soil bacteria individual species count was highest under the mangrove ecological zone than that of the freshwater swamp ecological (FWS) zone.

Table 2: Frequency of Soil Bacteria Species in each soil profile in each Ecological Zone (Column)

\begin{tabular}{|l|l|l|l|l|l|l|l|l|}
\hline Soil Bacteria & \multicolumn{2}{l}{ Freshwater } & \multicolumn{3}{l|}{ Mangrove } \\
\cline { 2 - 10 } & $0-15 \mathrm{~cm}$ & $15-30 \mathrm{~cm}$ & $30-45 \mathrm{~cm}$ & Total & $0-15 \mathrm{~cm}$ & $\begin{array}{l}15- \\
30 \mathrm{~cm}\end{array}$ & $30-45 \mathrm{~cm}$ & Total \\
\hline Bacillus & 16 & 14 & 12 & 42 & 15 & 13 & 20 & 48 \\
\hline Pseudomonas & 6 & 13 & 16 & 35 & 13 & 16 & 13 & 42 \\
\hline Micrococcus & 2 & 0 & 0 & 2 & 10 & 6 & 4 & 20 \\
\hline
\end{tabular}


International Journal of Agriculture, Environment and Bioresearch

Vol. 06, No. 03; 2021

ISSN: $2456-8643$

\begin{tabular}{|l|l|l|l|l|l|l|l|l|}
\hline Aeromonas & 14 & 10 & 16 & 40 & 16 & 16 & 7 & 39 \\
\hline Enterobaeter & 10 & 15 & 8 & 33 & 7 & 10 & 11 & 28 \\
\hline Salmonella & 2 & 2 & 2 & 6 & 11 & 10 & 12 & 33 \\
\hline Staphylococcus & 16 & 9 & 2 & 27 & 5 & 7 & 0 & 12 \\
\hline Protens & 0 & 0 & 0 & 0 & 2 & 4 & 0 & 6 \\
\hline Flavobacterium & 0 & 0 & 4 & 4 & 0 & 0 & 0 & 0 \\
\hline Total & $\mathbf{6 6}$ & $\mathbf{6 3}$ & $\mathbf{6 0}$ & $\mathbf{1 8 9}$ & $\mathbf{7 9}$ & $\mathbf{8 2}$ & $\mathbf{6 7}$ & $\mathbf{2 2 8}$ \\
\hline
\end{tabular}

$\mathrm{N}=60$

The frequency of soil fungi in sampled freshwater swamp and mangrove ecological zones in the study area is displayed on Table 3. The frequency of abundance of soil fungi of Rhizopus at varying soil depths revealed lowest abundance of (4) in soil depth of $0-15 \mathrm{~cm}$ and $30-45 \mathrm{~cm}$ under the FWS zone and highest abundance of (14) and (12) under mangrove ecological zone at soil depths of $0-15 \mathrm{~cm}$ and $15-30 \mathrm{~cm}$ respectively. The frequency of abundance of Aspergilus showed lowest abundance of (8) at soil depth of $30-45 \mathrm{~cm}$ under the FWS zone and highest frequency of abundance at soil depths of $15-30 \mathrm{~cm}$ and $30-45 \mathrm{~cm}$ at both FWS zone and M zone in the study area. The frequency of abundance of Penicillum showed lowest value of 8 at soil depth of 15-30 (M zone) and highest value of $16(15-30 \mathrm{~cm})$ and $16(30-45 \mathrm{~cm})$ under the FWS zone. The abundance of Gentricum varied across soil depths and ecological zones, whereby, lowest frequencies of abundance (3, 7, and 8) were recorded at mangrove ecological zones when compared with 18, 11 and 10 frequency values recorded at the freshwater swamp ecological zone in the study area. The abundance of Euglena ranged between 2 (soil depths of 15-30cm and 30$45 \mathrm{~cm}$ under FWS zone) and 9 (soil depth of $0-15 \mathrm{~cm}$ under the MG zone). The percentage frequency of soil fungi within each soil depth in the ecological zones is displayed on Table 4.50. Within the topsoil $(0-15 \mathrm{~cm})$ in the freshwater ecological zone, the results reveal that Rhizopus was the least in abundance with $6.90 \%$ while Gentricum was the highest with $31.03 \%$. However, the abundance of Euglena was the least at the soil depths of $15-30 \mathrm{~cm}$ and $30-45 \mathrm{~cm}$ with $4 \%$ and $5 \%$ respectively while Penicillum was the highest with $32 \%$ in the soil depth of $15-30 \mathrm{~cm}$ and $40 \%$ in the soil depth of $30-45 \mathrm{~cm}$. The total abundance of each identified fungi in the freshwater ecosystem reveals that Penicillum was the highest (32.00\%), followed by Gentricum (26.35\%), followed by Aspergilus (25\%), followed by Rhizopus (9.46\%) and the least was Euglena $(6.12 \%)$. 
Table 3: Frequency of Soil Fungi in the Ecological Zones

\begin{tabular}{|l|l|l|l|l|l|l|l|l|l|}
\hline \multirow{2}{*}{ Soil Fungi } & \multicolumn{4}{l}{ Freshwater } & \multicolumn{4}{l|}{ Mangrove } & \multicolumn{2}{l|}{$\begin{array}{l}\text { Grand } \\
\text { Total }\end{array}$} \\
\cline { 2 - 10 } & $0-15$ & $15-30$ & $30-45$ & Total & $0-15$ & $15-30$ & $30-45$ & Total & \\
\hline Rhizopus & 4 & 6 & 4 & 14 & 14 & 12 & 6 & 32 & 46 \\
\hline Aspergilus & 14 & 15 & 8 & 37 & 13 & 13 & 15 & 41 & 78 \\
\hline Penicillum & 14 & 16 & 16 & 46 & 10 & 8 & 13 & 31 & 77 \\
\hline Gentricum & 18 & 11 & 10 & 39 & 3 & 7 & 8 & 18 & 57 \\
\hline Euglena & 8 & 2 & 2 & 12 & 9 & 6 & 6 & 21 & 33 \\
\hline Total & 58 & 50 & 40 & 148 & 49 & 46 & 48 & 143 & $\mathbf{2 9 1}$ \\
\hline
\end{tabular}

$\mathrm{N}=20$

The frequency of soil arthropods across ecological zones is displayed on Table 4 . The frequency of Millipedes was highest with 20 at soil depth of $0-15 \mathrm{~cm}$ under FWS zone when compared with the highest of 13 at soil depth of $0-15 \mathrm{~cm}$ under the $\mathrm{M}$ zone. The frequency of Centipedes was highest (25) at soil depth of $0-15 \mathrm{~cm}$ under the FWS zone that the frequency of 16 at soil depth of $0-15 \mathrm{~cm}$ under the $\mathrm{M}$ zone. The frequencies of Beetles (37), Spiders (55) and Pseudoscorpion (15) were all higher at soil depth of $0-15 \mathrm{~cm}$ under the FWS zone than their frequencies of 31,35 and 6 at soil depth of $0-15 \mathrm{~cm}$ under the $\mathrm{M}$ zone. Generally, soil arthropods were abundant at soil depth of $0-15 \mathrm{~cm}$ than at soil depths of $15-30 \mathrm{~cm}$ and soil depth of $30-45 \mathrm{~cm}$ (which recorded the lowest in terms of frequencies of soil arthropods) in the study area.

Table 4: Frequency of Soil Arthropods

\begin{tabular}{|l|l|l|l|l|l|l|l|l|}
\hline \multirow{2}{*}{ Arthropods } & \multicolumn{4}{l}{ Freshwater } & \multicolumn{3}{l|}{ Mangrove } \\
\cline { 2 - 9 } & $0-15$ & $15-30$ & $30-45$ & Total & $0-15$ & $15-30$ & $30-45$ & Total \\
\hline Millipedes & 20 & 3 & 0 & 23 & 13 & 3 & 0 & 16 \\
\hline Centipedes & 25 & 5 & 0 & 30 & 16 & 2 & 0 & 18 \\
\hline Beetles & 37 & 10 & 3 & 50 & 31 & 8 & 1 & 40 \\
\hline Spiders & 55 & 5 & 0 & 60 & 35 & 4 & 0 & 39 \\
\hline Pseudoscorpion & 15 & 7 & 3 & 25 & 6 & 5 & 0 & 11 \\
\hline Total & 152 & 30 & 6 & 188 & 101 & 22 & 1 & 124 \\
\hline
\end{tabular}

$\mathrm{N}=20$ 
The species composition and number individuals per species of vascular plants across the ecological zones are shown in Table 5. A total of 41 different tree species were found in the entire study area whereby $19(46.3 \%)$ were found in the mangrove and $27(65.9 \%)$ were found in the freshwater ecological zone. A total of $572(42.1 \%)$ tree stands were recorded in the mangrove and $788(57.9 \%)$ were recorded in the freshwater ecological zone; suggesting that 1360 different tree species were found in the entire study area. In the freshwater ecological zone, tree species like Bambusa vulgaris, Cleistopholis patens, Elaeis guineensis, and Harungana madagascariensis were higher than other trees. However, in the mangrove ecological zone, Nypa fruticans was the highest tree species having $26 \%$. In total, Elaeis guineensis was the highest by having $12.9 \%$, followed by Nypa fruticans was the next by having $11 \%$, Bambusa vulgaris had $8.4 \%$ and Musanga cecroipoides had 8.3\%. The percentage of appearance of tree species in the entire study area showed that $5(12.2 \%)$ of the species were found in both ecological zones and these included Bambusa vulgaris, Baphia nitida, Elaeis guineensis, Harungana madagascariensis and Musanga cecroipoides.

Table 5: Species Composition of Plants in the Ecological Zones

\begin{tabular}{|c|c|c|c|c|c|c|}
\hline \multirow[t]{2}{*}{ Trees } & \multicolumn{2}{|l|}{ Mangrove } & \multicolumn{2}{|c|}{ Freshwater } & \multirow{2}{*}{$\begin{array}{l}\text { Total } \\
\text { Frequenc } \\
\mathrm{y}\end{array}$} & \multirow{2}{*}{$\begin{array}{l}\text { Total } \\
\text { Percenta } \\
\text { ge }(\%)\end{array}$} \\
\hline & $\begin{array}{l}\text { Frequenc } \\
\mathrm{y}\end{array}$ & $\begin{array}{l}\text { Percenta } \\
\text { ge }(\%)\end{array}$ & $\begin{array}{l}\text { Frequenc } \\
\mathrm{y}\end{array}$ & $\begin{array}{l}\text { Percenta } \\
\text { ge }(\%)\end{array}$ & & \\
\hline Acanthus mollis & 6 & 1.0 & 0 & 0 & 6 & 0.4 \\
\hline Alchornea cordifolia & 21 & 3.7 & 59 & 8.0 & 80 & 5.9 \\
\hline Alstonia boonei & 0 & 0 & 27 & 3.0 & 27 & 2.0 \\
\hline Anthocleista grandiflora & 0 & 0 & 10 & 1.3 & 10 & 0.7 \\
\hline Anthocleisti vogelii & 0 & 0 & 38 & 5.1 & 38 & 2.8 \\
\hline Anthonotha macrophylla & 0 & 0 & 5 & 0.7 & 5 & 0.4 \\
\hline Aubrevillea platycarpa & 0 & 0 & 7 & 0.9 & 7 & 0.5 \\
\hline Avicennia marina & 34 & 5.9 & 0 & 0 & 34 & 2.5 \\
\hline Bambusa vulgaris & 31 & 5.4 & 83 & 11.2 & 114 & 8.4 \\
\hline Baphia nitida & 14 & 2.4 & 20 & 2.7 & 34 & 2.5 \\
\hline Boscia mossambicensis & 0 & 0 & 7 & 0.9 & 7 & 0.5 \\
\hline Bridelia micrantha & 0 & 0 & 27 & 3.6 & 27 & 2.0 \\
\hline
\end{tabular}


Vol. 06, No. 03; 2021

ISSN: $2456-8643$

\begin{tabular}{|l|l|l|l|l|l|l|}
\hline Casuarina equisetifolia & 6 & 1.0 & 0 & 0 & 6 & 0.4 \\
\hline Cleistopholis patens & 0 & 0 & 84 & 11.3 & 84 & 6.2 \\
\hline Cocos nucifera & 6 & 1.0 & 0 & 0 & 6 & 0.4 \\
\hline Dalbergia spp & 6 & 1.0 & 0 & 0 & 6 & 0.4 \\
\hline Dracaena mannii & 4 & 0.7 & 0 & 0 & 4 & 0.3 \\
\hline Elaeis guineensis & 81 & 14.2 & 95 & 12.8 & 176 & 12.9 \\
\hline Erythrina spp & 8 & 1.4 & 0 & 0 & 8 & 0.6 \\
\hline Gliricidia spp & 12 & 2.1 & 0 & 0 & 12 & 0.9 \\
\hline Gmelina arboreal & 0 & 0 & 37 & 4.5 & 37 & 2.7 \\
\hline $\begin{array}{l}\text { Harungana } \\
\text { madagascariensis }\end{array}$ & 12 & 2.1 & 71 & 9.3 & 83 & 6.1 \\
\hline Irvingia gabonensis & 0 & 0 & 14 & 1.3 & 14 & 1.0 \\
\hline Laguncularia racemosa & 23 & 4.0 & 0 & 0 & 23 & 1.7 \\
\hline Macaranga barterii & 0 & 0 & 14 & 3.4 & 14 & 1.0 \\
\hline Mangifera indica & 0 & 0 & 25 & 0.9 & 25 & 1.8 \\
\hline Milicia aboensis & 0 & 0 & 7 & & 7 & 0.5 \\
\hline Musanga cecroipoides & 80 & 14.0 & 33 & 4.5 & 113 & 8.3 \\
\hline Nypa fruticans & 149 & 26.0 & 0 & 0 & 149 & 11.0 \\
\hline Papilionacea spp & 2 & 0.3 & 0 & 0 & 2 & 0.1 \\
\hline Pentaclethra macrophylla & 0 & 0 & 16 & 0.5 & 16 & 1.2 \\
\hline $\begin{array}{l}\text { Piptadeniastrum } \\
\text { africanum }\end{array}$ & 0 & 0 & 2 & 0.3 & 2 & 0.1 \\
\hline Psidium guajava & 0 & 0 & 14 & 1.9 & 14 & 1.0 \\
\hline $\begin{array}{l}\text { Pterocarpus } \\
\text { santhalinoides }\end{array}$ & 0 & 0 & 6 & 0.3 & 6 & 0.4 \\
\hline Rauvolfia vomitoria & 0 & 0 & 49 & 6.6 & 49 & 3.6 \\
\hline
\end{tabular}


ISSN: $2456-8643$

\begin{tabular}{|l|l|l|l|l|l|l|}
\hline Rhizophora mangle & 39 & 6.8 & 0 & 0 & 39 & 2.9 \\
\hline Rhizophora racemosa & 38 & 6.6 & 0 & 0 & 38 & 2.8 \\
\hline Trilepsin spp & 0 & 0 & 13 & 1.8 & 13 & 1.0 \\
\hline Uapaca heudulotii & 0 & 0 & 3 & 0.1 & 3 & 0.2 \\
\hline Vitex grandiflora & 0 & 0 & 15 & 2.0 & 15 & 1.1 \\
\hline Zanthoxylum tessmannii & 0 & 0 & 7 & 0.9 & 7 & 0.5 \\
\hline Total & $\mathbf{5 7 2}$ & $\mathbf{1 0 0 . 0}$ & $\mathbf{7 8 8}$ & $\mathbf{1 0 0 . 0}$ & $\mathbf{1 3 6 0}$ & $\mathbf{1 0 0 . 0}$ \\
\hline
\end{tabular}

Number of Individual Tree Species, Total Number of Tree Stand, Species Diversity Richness and Density

The mean tree composition and total number of tree stands in both FWS and MG ecological zones are shown in Table 6. It is shown that the mean tree composition of the freshwater was 7.9 while that of mangrove was 6.2. Pertaining to the mean number of tree stand, it was discovered that freshwater had 39.4 while mangrove had 28.6. The species diversity of tree species in the study area revealed that freshwater had 0.8622 while mangrove had 0.8457 (Table 7). The mean species richness in Table 8 reveals that freshwater had 1.1335 while mangrove had 1.1228. The mean species density of trees in the study area also show that freshwater had 0.204 tree/ha while mangrove had 0.191 tree/ha (Table 9).

Table 6: Number of Individual Trees Species and Total Number of Tree Stand by Plot

\begin{tabular}{|l|l|l|l|l|}
\hline \multirow{2}{*}{ Plots } & \multicolumn{2}{|l|}{ Freshwater Swamp } & \multicolumn{2}{l|}{ Mangrove } \\
\cline { 2 - 5 } & Tree Composition & Number of Tree Stand & $\begin{array}{l}\text { Number of Tree } \\
\text { Species }\end{array}$ & $\begin{array}{l}\text { Number of Tree } \\
\text { Stand }\end{array}$ \\
\hline $\mathbf{1}$ & 14 & 71 & 7 & 31 \\
\hline $\mathbf{2}$ & 12 & 46 & 9 & 21 \\
\hline $\mathbf{3}$ & 8 & 35 & 5 & 25 \\
\hline $\mathbf{4}$ & 6 & 33 & 5 & 36 \\
\hline $\mathbf{5}$ & 7 & 44 & 6 & 35 \\
\hline $\mathbf{6}$ & 6 & 36 & 6 & 24 \\
\hline $\mathbf{7}$ & 6 & 32 & 6 & 31 \\
\hline
\end{tabular}


International Journal of Agriculture, Environment and Bioresearch

Vol. 06, No. 03; 2021

ISSN: $2456-8643$

\begin{tabular}{|c|c|c|c|c|}
\hline 8 & 7 & 31 & 5 & 20 \\
\hline 9 & 8 & 24 & 4 & 16 \\
\hline 10 & 9 & 45 & 5 & 19 \\
\hline 11 & 10 & 54 & 6 & 20 \\
\hline 12 & 9 & 43 & 6 & 24 \\
\hline 13 & 7 & 40 & 8 & 26 \\
\hline 14 & 7 & 39 & 7 & 33 \\
\hline 15 & 6 & 39 & 7 & 48 \\
\hline 16 & 8 & 45 & 8 & 41 \\
\hline 17 & 5 & 25 & 8 & \begin{tabular}{|l|l}
40 \\
\end{tabular} \\
\hline 18 & 7 & 34 & 6 & 40 \\
\hline 19 & 7 & 29 & 5 & 23 \\
\hline 20 & 8 & 43 & 4 & 19 \\
\hline Total & 157 & 788 & 123 & 572 \\
\hline Mean & $7.9 \pm 2.2$ & $39.4 \pm 10.6$ & $6.2 \pm 1.4$ & $28.6 \pm 9.05$ \\
\hline
\end{tabular}

Table 7: Species Diversity of Plant Species in the Ecological Zones

\begin{tabular}{|l|l|l|}
\hline Plots & Freshwater & Mangrove \\
\hline $\mathbf{1}$ & 0.9219 & 0.8301 \\
\hline $\mathbf{2}$ & 0.9284 & 0.9333 \\
\hline $\mathbf{3}$ & 0.8857 & 0.8430 \\
\hline $\mathbf{4}$ & 0.8852 & 0.7441 \\
\hline $\mathbf{5}$ & 0.8309 & 0.7720 \\
\hline $\mathbf{6}$ & 0.8429 & 0.9118 \\
\hline $\mathbf{7}$ & 0.7944 & 0.8129 \\
\hline
\end{tabular}


International Journal of Agriculture, Environment and Bioresearch

Vol. 06, No. 03; 2021

ISSN: $2456-8643$

\begin{tabular}{|l|l|l|}
\hline $\mathbf{8}$ & 0.8194 & 0.9118 \\
\hline $\mathbf{9}$ & 0.8918 & 0.9290 \\
\hline $\mathbf{1 0}$ & 0.8869 & 0.9290 \\
\hline $\mathbf{1 1}$ & 0.8973 & 0.9334 \\
\hline $\mathbf{1 2}$ & 0.8837 & 0.9075 \\
\hline $\mathbf{1 3}$ & 0.8654 & 0.9247 \\
\hline $\mathbf{1 4}$ & 0.8556 & 0.8086 \\
\hline $\mathbf{1 5}$ & 0.8581 & 0.6710 \\
\hline $\mathbf{1 6}$ & 0.8737 & 0.7570 \\
\hline $\mathbf{1 7}$ & 0.8200 & 0.7720 \\
\hline $\mathbf{1 8}$ & 0.7806 & 0.7204 \\
\hline $\mathbf{1 9}$ & 0.8596 & 0.8882 \\
\hline $\mathbf{2 0}$ & 0.8634 & 0.9140 \\
\hline Mean \pm SD & $\mathbf{0 . 8 6 2 2 \pm \mathbf { 0 . 0 4 }}$ & $\mathbf{0 . 8 4 5 7} \pm \mathbf{0 . 0 8}$ \\
\hline
\end{tabular}

Table 8: Species Richness of Plant Species in the Ecological Zones

\begin{tabular}{|l|l|l|}
\hline Plots & Freshwater & Mangrove \\
\hline $\mathbf{1}$ & 1.1897 & 0.9984 \\
\hline $\mathbf{2}$ & 0.7400 & 0.8211 \\
\hline $\mathbf{3}$ & 0.9492 & 1.2427 \\
\hline $\mathbf{4}$ & 1.287 & 1.7301 \\
\hline $\mathbf{5}$ & 1.3968 & 1.3594 \\
\hline $\mathbf{6}$ & 1.3953 & 0.9439 \\
\hline $\mathbf{7}$ & 1.2503 & 1.2134 \\
\hline $\mathbf{8}$ & 0.9984 & 1.0014 \\
\hline
\end{tabular}


International Journal of Agriculture, Environment and Bioresearch

Vol. 06, No. 03; 2021

ISSN: $2456-8643$

\begin{tabular}{|l|l|l|}
\hline $\mathbf{9}$ & 0.6293 & 1.082 \\
\hline $\mathbf{1 0}$ & 1.051 & 0.9509 \\
\hline $\mathbf{1 1}$ & 1.103 & 0.7788 \\
\hline $\mathbf{1 2}$ & 1.0044 & 0.9439 \\
\hline $\mathbf{1 3}$ & 1.2779 & 0.6906 \\
\hline $\mathbf{1 4}$ & 1.2478 & 1.0622 \\
\hline $\mathbf{1 5}$ & 1.5013 & 1.513 \\
\hline $\mathbf{1 6}$ & 1.215 & 1.1108 \\
\hline $\mathbf{1 7}$ & 1.2427 & 1.0843 \\
\hline $\mathbf{1 8}$ & 1.094 & 1.5361 \\
\hline $\mathbf{1 9}$ & 0.9333 & 1.1184 \\
\hline $\mathbf{2 0}$ & 1.1632 & 1.2736 \\
\hline Mean \pm SD & $\mathbf{1 . 1 3 3 5} \pm \mathbf{0 . 2 2}$ & $\mathbf{1 . 1 2 2 8} \pm \mathbf{0 . 2 6}$ \\
\hline & & \\
\hline
\end{tabular}

Table 9: Species Density (tree/ha) of Plant Species in the Ecological Zones

\begin{tabular}{|l|l|l|}
\hline Plots & Freshwater & Mangrove \\
\hline $\mathbf{1}$ & 0.203 & 0.18 \\
\hline $\mathbf{2}$ & 0.153 & 0.14 \\
\hline $\mathbf{3}$ & 0.175 & 0.2 \\
\hline $\mathbf{4}$ & 0.22 & 0.288 \\
\hline $\mathbf{5}$ & 0.2514 & 0.23 \\
\hline $\mathbf{6}$ & 0.24 & 0.16 \\
\hline $\mathbf{7}$ & 0.2133 & 0.21 \\
\hline $\mathbf{8}$ & 0.1771 & 0.16 \\
\hline $\mathbf{9}$ & 0.12 & 0.16 \\
\hline
\end{tabular}


Vol. 06, No. 03; 2021

ISSN: $2456-8643$

\begin{tabular}{|l|l|l|}
\hline $\mathbf{1 0}$ & 0.2 & 0.152 \\
\hline $\mathbf{1 1}$ & 0.216 & 0.133 \\
\hline $\mathbf{1 2}$ & 0.1911 & 0.16 \\
\hline $\mathbf{1 3}$ & 0.2286 & 0.13 \\
\hline $\mathbf{1 4}$ & 0.2229 & 0.189 \\
\hline $\mathbf{1 5}$ & 0.26 & 0.274 \\
\hline $\mathbf{1 6}$ & 0.225 & 0.205 \\
\hline $\mathbf{1 7}$ & 0.2 & 0.2 \\
\hline $\mathbf{1 8}$ & 0.194 & 0.27 \\
\hline $\mathbf{1 9}$ & 0.166 & 0.184 \\
\hline $\mathbf{2 0}$ & 0.215 & 0.19 \\
\hline Mean \pm SD & $\mathbf{0 . 2 0 4 \pm \mathbf { 0 . 0 3 }}$ & $\mathbf{0 . 1 9 1} \pm \mathbf{0 . 0 5}$ \\
\hline
\end{tabular}

Relationship between soil organisms and Tree Ecological Characteristics

The correlation analyses between the soil organisms at different soil depths and tree ecological parameters are presented in Tables 10, 11, and 12 for the both ecological zone. In the soil depth of $0-15 \mathrm{~cm}$ in freshwater ecological zone, it is revealed that earthworm abundance was correlated with tree composition $(r=-0.459)$; tree richness $(r=0.543)$ and tree density $(r=0.581)$. However, earthworm diversity was significantly correlated with tree density while earthworm richness was correlated significantly with tree richness $(\mathrm{r}=0.507)$ and tree density $(\mathrm{r}=0.551)$. The tree richness was correlated significantly and negatively with soil fungi abundance $(\mathrm{r}=-0.445)$; and soil fungi richness $(\mathrm{r}=-0.441)$; but positively with soil fungi diversity $(\mathrm{r}=0.443)$. Meanwhile, soil organisms at the depth of $15-30 \mathrm{~cm}$ in the freshwater ecological zone had some significant correlations with trees ecological parameters. The tree species composition was significantly correlated with soil bacteria diversity $(\mathrm{r}=0.658)$; soil fungi abundance $(\mathrm{r}=-0.668)$; soil fungi density $(\mathrm{r}=-0.650)$; soil fungi diversity $(\mathrm{r}=0.629)$ and soil fungi richness $(\mathrm{r}=-0.678)$. Tree species diversity was significantly and negatively correlated with earthworm diversity ( $\mathrm{r}=$ $0.523)$ and earthworm richness $(\mathrm{r}=-0.618)$. In addition, tree richness was significantly correlated with soil bacteria density $(\mathrm{r}=-0.446)$, soil bacteria diversity $(\mathrm{r}=-0.550)$, soil fungi abundance $(\mathrm{r}=0.550)$, soil fungi density $(\mathrm{r}=0.517)$, soil fungi diversity $(\mathrm{r}=-0.551)$ and soil fungi richness $(\mathrm{r}=$ 0.652 ). At the soil depth of $30-45 \mathrm{~cm}$ in the freshwater, it is found that soil bacteria abundance, density and richness only had significant correlations with tree species composition, richness, and density. It is found that tree composition had positive correlation with soil bacteria abundance $(\mathrm{r}=.514)$; soil bacteria density $(\mathrm{r}=0.558)$ and soil bacteria richness $(\mathrm{r}=0.553)$. Also, tree richness was significantly and negatively correlated with soil bacteria abundance ( $\mathrm{r}=$ - 
$0.624)$; soil bacteria density $(\mathrm{r}=-0.610)$ and soil bacteria density $(\mathrm{r}=-0.610)$. Tree density was significantly and negatively correlated with soil bacteria abundance $(\mathrm{r}=-0.464)$; soil bacteria density $(r=-0.478)$ and soil bacteria richness $(r=-0.458)$.

For the mangrove at the soil depth of $0-15 \mathrm{~cm}$, it is found that it was only soil fungi and arthropods abundance that had significant correlations with the tree ecological parameters. It is therefore shown that the tree composition had significant and positive correlations with soil arthropods density $(\mathrm{r}=0.406)$; soil arthropods richness $(\mathrm{r}=0.487)$; soil arthropods abundance $(\mathrm{r}=0.464)$ and negative but significant correlation with soil arthropods diversity $(\mathrm{r}=-0.478)$. On the other hand, tree species diversity was significantly correlated with soil fungi richness $(\mathrm{r}=$ $0.445)$; soil fungi abundance $(\mathrm{r}=-0.474)$; soil fungi diversity $(\mathrm{r}=0.485)$ and soil fungi density $(\mathrm{r}=$ -0.497 ). At the soil depth of $15-30 \mathrm{~cm}$ in the mangrove, results showed that the number of tree stands correlated significantly with soil fungi richness, abundance, diversity and density while tree species diversity, tree species richness and tree species density was each correlated with soil bacteria density, diversity, richness and abundance; and soil fungi richness, abundance, diversity and density. At the soil depth of $30-45 \mathrm{~cm}$, number of tree stands correlated significantly with soil fungi richness $(r=0.489)$, abundance $(r=0.474)$, diversity $(r=0.460)$ and density $(r=0.475)$. It is recorded that soil bacteria diversity was significantly correlated with tree diversity $(r=-0.491)$; tree richness $(\mathrm{r}=0.477)$ and tree density $(\mathrm{r}=0.534)$.

Table 9: Spearman's Rank Correlations between Soil Organisms abundance and Tree Ecological Parameters at 0-15cm Soil Depth

\begin{tabular}{|l|l|l|l|l|l|l|}
\hline $\begin{array}{l}\text { Ecological } \\
\text { Zones }\end{array}$ & & $\begin{array}{l}\text { Tree } \\
\text { Species } \\
\text { Compositi } \\
\text { on }\end{array}$ & $\begin{array}{l}\text { Number of } \\
\text { Tree Stand }\end{array}$ & $\begin{array}{l}\text { Tree } \\
\text { Specie } \\
\text { s } \\
\text { Divers } \\
\text { ity }\end{array}$ & $\begin{array}{l}\text { Tree } \\
\text { Specie } \\
\text { s } \\
\text { Richne } \\
\text { ss }\end{array}$ & $\begin{array}{l}\text { Tree } \\
\text { Speci } \\
\text { es } \\
\text { Densi } \\
\text { ty }\end{array}$ \\
\hline Freshwater & Earthworm & $-.459^{*}$ & -.113 & -.378 & $.543^{*}$ & $.581^{*}$ \\
\cline { 2 - 7 } & Soil Bacteria & .375 & .285 & .349 & -.040 & -.057 \\
\cline { 2 - 7 } & Soil Fungi & .095 & -.362 & .065 & $-.445^{*}$ & -.380 \\
\cline { 2 - 7 } & Soil Arthropods & .084 & .202 & .188 & .165 & .275 \\
\hline \multirow{4}{*}{ Mangrove } & Earthworm & .196 & -.088 & .156 & -.202 & -.160 \\
\cline { 2 - 8 } & Soil Bacteria & .013 & .008 & -.023 & .057 & .046 \\
\cline { 2 - 8 } & Soil Fungi & .018 & .374 & $-.474^{*}$ & .317 & .403 \\
\cline { 2 - 8 } & Soil Arthropods & $.464^{*}$ & -.001 & .178 & -.479 & -.375 \\
\hline
\end{tabular}

${ }^{*}$ Correlation is significant at $\mathrm{p}<0.05 ; \mathrm{N}=20$ 
Table 10: Spearman's Rank Correlations of Soil Organisms and Tree Ecological Parameters at $15-30 \mathrm{~cm}$ Soil Depth

\begin{tabular}{|l|l|l|l|l|l|l|}
\hline Ecological Zones & & $\begin{array}{l}\text { Tree } \\
\text { Species } \\
\text { Composit } \\
\text { ion }\end{array}$ & $\begin{array}{l}\text { Number } \\
\text { of Tree } \\
\text { Stand }\end{array}$ & $\begin{array}{l}\text { Tree } \\
\text { Specie } \\
\text { s } \\
\text { Divers } \\
\text { ity }\end{array}$ & $\begin{array}{l}\text { Tree } \\
\text { Specie } \\
\text { s } \\
\text { Richn } \\
\text { ess }\end{array}$ & $\begin{array}{l}\text { Tree } \\
\text { Speci } \\
\text { es } \\
\text { Densi } \\
\text { ty }\end{array}$ \\
\hline $\begin{array}{l}\text { Freshwater } \\
\text { Swamp }\end{array}$ & Earthworm & -.136 & .050 & -.143 & .246 & .371 \\
\cline { 2 - 8 } & Soil Bacteria & .374 & .077 & .330 & -.412 & -.371 \\
\cline { 2 - 8 } & Soil Fungi & $-.668^{*}$ & -.307 & -.221 & $.550^{*}$ & .412 \\
\cline { 2 - 8 } & Soil Arthropods & .081 & -.137 & .393 & -.221 & -.167 \\
\hline \multirow{4}{*}{ Mangrove } & Earthworm & .106 & .164 & -.081 & .171 & .190 \\
\cline { 2 - 8 } & Soil Bacteria & -.107 & .375 & $-.549^{*}$ & $.582^{*}$ & $.570^{*}$ \\
\cline { 2 - 8 } & Soil Fungi & .172 & $.611^{*}$ & $-.624^{*}$ & $.520^{*}$ & $.632^{*}$ \\
\cline { 2 - 8 } & Soil Arthropods & -.252 & -.101 & -.062 & .238 & .161 \\
\hline
\end{tabular}

${ }^{*}$ Correlation is significant at $\mathrm{p}<0.05 ; \mathrm{N}=20$

Table 11: Spearman's Rank Correlations of Soil Organisms and Tree Ecological Parameters at $30-45 \mathrm{~cm}$ Soil Depth

\begin{tabular}{|l|l|l|l|l|l|l|}
\hline $\begin{array}{l}\text { Ecological } \\
\text { Zones }\end{array}$ & & $\begin{array}{l}\text { Tree Species } \\
\text { Composition }\end{array}$ & $\begin{array}{l}\text { Number } \\
\text { of Tree } \\
\text { Stand }\end{array}$ & $\begin{array}{l}\text { Tree } \\
\text { Species } \\
\text { Diversity }\end{array}$ & $\begin{array}{l}\text { Tree } \\
\text { Species } \\
\text { Richness }\end{array}$ & $\begin{array}{l}\text { Tree } \\
\text { Species } \\
\text { Density }\end{array}$ \\
\hline $\begin{array}{l}\text { Freshwater } \\
\text { Swamp }\end{array}$ & Earthworm & .317 & .332 & .276 & -.069 & -.036 \\
\cline { 2 - 7 } & Soil Bacteria & $.514^{*}$ & .247 & .328 & $-.624^{*}$ & $-.464^{*}$ \\
\cline { 2 - 7 } & Soil Fungi & -.087 & -.222 & -.289 & -.120 & -.141 \\
\cline { 2 - 7 } & Soil Arthropods & .156 & .274 & .049 & .052 & .212 \\
\hline Mangrove & Earthworm & .306 & .203 & -.096 & .053 & .123 \\
\cline { 2 - 7 } & Soil Bacteria & .342 & .072 & .074 & -.196 & -.104 \\
\cline { 2 - 7 } & Soil Fungi & .405 & $.474^{*}$ & -.329 & .125 & .286 \\
\hline
\end{tabular}


Vol. 06, No. 03; 2021

ISSN: $2456-8643$

\begin{tabular}{|l|l|l|l|l|l|l|}
\hline & Soil Arthropods & -.235 & -.124 & .047 & .114 & -.054 \\
\hline
\end{tabular}

${ }^{*}$ Correlation is significant at $\mathrm{p}<0.05 ; \mathrm{N}=20$

\section{DISCUSSIONS}

The significant relationship between abundance of earthworm and tree richness, tree composition and tree density is an indication of soil fertility improvement especially at the topsoil. Plant interactions and feedbacks with soil biota determine ecosystem functioning and primary productivity in terrestrial habitats (Bagchi et al., 2014; Wagg et al., 2014). Different levels of correlations between tree ecological parameters and soil organisms can be linked with chemical composition and microbial biomass. Tedersoo et al (2016) reported that tree species differ substantially in the quality of their litter that determines the chemical composition and microbial biomass directly or indirectly by stimulating earthworm activity. Also, Aponte et al (2013) reported that soil and litter quality affect degradation rates and community composition of saprotrophic and EcM fungi.

\section{CONCLUSION AND RECOMMENDATIONS}

The study can be concluded that tree composition, density, richness and diversity have important roles to play on the abundance of soil organisms at different soil profiles. It is therefore recommended tree conservation is necessary to conserve the soil organisms in all ecological zones of Bayelsa State, Nigeria. More studies are required to give room for periodic monitoring of the abundance of soil organisms under different landuse types.

\section{REFERENCES}

Aanen D.K., Henrik H., Debets A.J., Kerstes N.A., Hoekstra R.F. and Boomsma J.J. (2009): High symbiont relatedness stabilizes mutualistic cooperation in fungus-growing termites. Science 326:1103-1106

Adhikari K. and Hartemink A.E. (2015). Linking soils to ecosystem services-A global review. Geoderma 262: 101-111.

Ahrens D, Schwarzer J, Vogler AP (2014) The evolution of scarab beetles tracks the sequential rise of angiosperms and mammals. Proc R Soc Lond B 281:20141470

Bagchi R, Gallery R.E., Gripenberg S., Gurr S.J., Narayan L., Addis C.E., Freckleton R.P. \& Lewis O.T. (2014): Pathogens and insect herbivores drive rainforest plant diversity and composition. Nature 506: 85-88.

Baveye PC, Baveye J and Gowdy J (2016) Soil "Ecosystem" Services and Natural Capital: Critical Appraisal of Research on Uncertain Ground. Front. Environ. Sci. 4:41. doi: 10.3389/fenvs.2016.00041

Chandra, L.R., Gupta, S., Pande, V. et al. Impact of forest vegetation on soil characteristics: a correlation between soil biological and physico-chemical properties. 3 Biotech 6, 188 (2016). https://doi.org/10.1007/s13205-016-0510-y 
Chima U.D. and Omokhua G.E. (2011): Vegetation Assessment and Description. In Aiyeloja A.A. and Ijeomah H.M (Eds): Book of reading in Forestry, Wildlife Management and Fisheries. 104-129.

Condit R., Engelbrecht B.M.J., Pino D., Pe'rez R., and Turner B.L. (2013).Species distributions in response to individual soil nutrients and seasonal drought across a community of tropical trees. Proc Nat Acad Sci 110:5064-5068

Corlett R.T. and Primack R.B. (2006): Tropical rainforests and the need for cross-continental comparisons. Trends Ecol Evol 21:104-110

Davies R.G., Eggleton P., Jones D.T., Gathorne-Hardy F.J., and Hernandez L.M. (2003). Evolution of termite functional diversity: analysis and synthesis of local ecological and regional influences on local species richness. J Biogeogr 30:847-877.

Ettema, C. H., \& Wardle, D. A. (2002). Spatial soil ecology. Trends in Ecology and Evolution, 17:177-183.

Fitter, A.H., Gilligan, C. A., Hollingworth, K., Kleczkowski, A., Twyman, R.M., Pitchford J. W. and The Members of the NERC Soil Biodiversity Programme (2005): Biodiversity and ecosystem function in soil. Functional Ecology, 19:369-377

Foissner W. (2006): Biogeography and dispersal of micro-organisms:a review emphasizing protists. Act Protozool 45:111-136

Fujii K., Shibata M., Kitajima K., Ichie K., Kitayama K. \& Turner B.L. (2018). Plant-soil interactions maintain biodiversity and functions of tropical forest ecosystems. Ecol Res (2018) 33: 149-160. DOI 10.1007/s11284-017-1511-y

Hayakawa C, Funakawa S, Fujii K, Kadono A, and Kosaki T (2013).Effects of climatic and soil properties on cellulose decomposition rates in temperate and tropical forests. Biol Fertil Soil50:633-643

Landesman W and Dighton J (2011): Shifts in microbial biomass and the bacteria: fungi ratio occur under field conditions within $3 \mathrm{~h}$ after rainfall. Microb Ecol 62:228-236. doi:10.1007/s00248-011-9811-1

Margalef, R., (1958). Temporal succession and spatial heterogeneity in phytoplankton. In: Perspectives in Marine biology, Buzzati-Traverso (ed.), Univ. Calif. Press, Berkeley, 323347.

North R.D., Jackson C.W., and Howse PE (1997) Evolutionary aspects of ant-fungus interactions in leaf-cutting ants. Trends Ecol Evol12:386-389

Ologunorisa T.E. and Adejuwon J.O. (2003). Annual rainfall trends and periodicities in the Niger Delta, Nigeria. Journal of Meteorology 28(276): 41-51.

Rousk J, Baath E, Brookes P.C., Lauber C.L., Lozupone C, Caporaso J.G., Knight R, and Fierer N (2010) Soil bacterial and fungal communities across a pH gradient in an arable soil. ISME4:1340-1351

Shen H. (2011). Land Use Spatial Pattern Characteristics along the Terrain Gradient in Yellow River Basin in West Henan Province, China. IEEE; 1-5.

Sollins P (1998): Factors influencing species composition in tropical lowland rain forest: does soil matter? Ecology 79:23-30.

Tedersoo, L., Bahram, M., Cajthaml, T., Põlme, S., Hiiesalu, I., Anslan, S., Harend, H., Buegger, F., Pritsch, K., Koricheva, J., \& Abarenkov, K. (2016). Tree diversity and species identity 
effects on soil fungi, protists and animals are context dependent. The ISME journal, 10(2), 346-362. https://doi.org/10.1038/ismej.2015.116

Umeuduji, J. E and Aisuebeogun, A., (1999). Relief and Drainage. In C. U. Oyegun and A. Adeyemo, (eds.): Port Harcourt Region, Port Harcourt: Department of Geography and

Vitousek P.M. (2004) Nutrient cycling and limitation: Hawai'i as a model system. Princeton University Press, Princeton

Weng J.K. and Chapple C. (2010): The origin and evolution of lignin biosynthesis. New Phytol 187:273-285

Williams, S. E., Marsh, H., \& Winter, J. (2002). Spatial scale, species diversity and habitat structure: small mammals in Australian tropical rainforest. Ecology, 83:1317-1329.

Young I.M. and Ritz K. (2000). Tillage, habitat space and function of soil microbes. Soil Till Res 53: 201-213 DOI: 10.1016/S0167-1987(99)00106-3 